Medieval Studies, vol. 22, 2018 / Studia z Dziejów Średniowiecza, tom 22, 2018

\author{
Błażej Śliwiński
}

(University of Gdańsk)

https://orcid.org/ 0000-0001-6365-9839

\title{
Czech involvement in King Henry V of Germany's expedition against Poland in September 1109 from the perspective of Polish historiography
}

Keywords: Bolesław Krzywousty, Zbigniew, King Henry V of Germany, Jan Długosz, Psie Pole

In August and September 1109, a war was fought between Henry V, King of Germany, and Prince Bolesław Krzywousty (Boleslaus Wrymouth) of Poland. Henry's expedition against Poland was a response to the Polish ruler's actions of the previous year, when his attack on Bohemia sparked the fiasco of the German expedition to Hungary. It was then that King Henry $\mathrm{V}$ had vowed to exact his revenge on Bolesław Krzywousty. ${ }^{1}$ Henry was encouraged to retaliate by the Czech duke Svatopluk, ${ }^{2}$ not only as a means of gaining revenge for earlier events, but also because Svatopluk's rival for the throne, Borivoj, ousted in 1107, had found sanctuary in Poland. Before the war, the German king had sent an envoy demanding that Bolesław Krzywousty reinstate his older brother Zbigniew, who had been removed from power and exiled from Poland. He also demanded that Bolesław pay a tribute of 300 silver grzywnas (marks) or supply 300 knights for

1 Cosmae Pragensis Chronica Boemorum, ed. B. Bretholz, MGH SS, N.S., vol. 2, Berolini 1923, lib. III, c. 22, p. 189; the subject of Henry V's vengeance for the Hungarian debacle is mentioned in 'Kronika wielkopolska;' see Chronica Poloniae Maioris, ed. B. Kürbis, MPH s.n., vol. 8, Warszawa 1970, cap. 25, p. 36.

2 Galli Anonymi Cronicae et gesta ducum sive principum Polonorum, ed. K. Maleczyński, MPH s.n., vol. 2, Kraków 1952, lib. III, cap. 3. 
an expedition (to Italy, where Henry V intended to assume the crown of the Holy Roman Empire). ${ }^{3}$

It is mainly in Polish historiography ${ }^{4}$ that the German-Czech expedition to Poland came to attract great interest. ${ }^{5}$ Attention focused primarily on events that ultimately attained legendary status (the pivotal point of the war, namely the siege of the Polish stronghold of Głogów [Glogau], including the capture of Polish hostages whom the Germans tied to their siege engines ${ }^{6}$ ), as well as on events that were simply made up years later and never actually took place (such as the crushing defeat of the German and Czech armies at the Battle

3 Gall, lib. III, cap. 2.

4 For Czech historiography, see the recent J. Fidler, 'Válecné akce ve Slezsku v létě 1109,' Historie a Vojenstvi, 50, 2001, pp. 1-9.

5 For major works, see K. Maleczyński, 'Wyprawa Henryka V na Polskę z r. 1109' [Henry V's expedition to Poland in 1109], Sprawozdania Towarzystwa Naukowego we Lwowie, 1, 1937, pp. 43-49; idem, Wojna polsko-niemiecka 1109 r. [The PolishGerman war of 1109], Wrocław 1946; idem, 'Ślask terenem wojen polsko-czeskich i polsko-niemieckich w latach 1102-1115' [Silesia: battleground of Polish-Czech and Polish-German wars, 1102-1115], Historia Ślqska, vol. 1, part 1, Wrocław 1960; idem, Bolesław III Krzywousty [Boleslaus III, Wrymouth], Wrocław-WarszawaKraków-Gdańsk 1975; W. Bortnowski, Walki w obronie niepodlegtości Polski w okresie wczesnofeudalnym [Battles in defence of Poland's independence in the early feudal period], Warszawa 1952, pp. 50-52; W. Korta, 'Z dziejów obrony Ślaska przed feudałami niemieckimi w XI i XII wieku' [The defence of Silesia against German feudalism in the eleventh and twelfth centuries], Szkice z dziejów Ślaska, vol. 1, ed. E. Maleczyńska, Warszawa 1955; idem, 'Jak doszło do Psiego Pola, w 850 rocznicę wojny polsko-niemieckiej z 1109 roku' [The events that led to the Battle of Psie Pole, on the 850th anniversary of the Polish-German war of 1109], Rocznik Wroctawski, 2, 1958; A.F. Grabski, Polska sztuka wojenna $w$ okresie wczesnofeudalnym [The art of Polish warfare in the early feudal period], Warszawa 1959; A. Kucner, 'O przebiegu wojny polsko-niemieckiej w roku 1109' [The course of the Polish-German war of 1109], Nadodrzańskie szkice historyczne, Zielona Góra 1960; B. Miśkiewicz, 'Przebieg bitew stoczonych w obronie granicy zachodniej Polski wczesnofeudalnej' [The course of battles fought in defence of early feudal Poland's western frontier], in: Nadodrzańskie szkice historyczne, Zielona Góra 1960; idem, Studia nad obrona polskiej granicy zachodniej $w$ okresie wczesnofeudalnym [Studies on the defence of early feudal Poland's western frontier], Poznań 1961; idem, 'Bitwa o Głogów w 1109 roku jako przykład ludowego charakteru obronności polski wczesnofeudalnej' [The 1109 Battle of Głogów as an example of the popular nature of the defence of early feudal Poland], in: Obronność polskiej granicy zachodniej $w$ dobie pierwszych Piastów, Wrocław-Warszawa-Kraków-Gdańsk-Łódź 1984; K. Olejnik, 'Cedynia, Niemcza, Głogów, Krzyszków,' in: Dzieje Narodu i Państwa Polskiego, vol. I, Kraków 1988, pp. 59-71; idem, Głogów 1109, Warszawa 1999.

6 In addition to numerous works in Polish, for more on this episode, see J. Szymczak, 'Glogow, Siege of,' in: The Oxford Encyclopedia of Medieval Warfare and Military Technology, vol. 1, ed. C.J. Rogers, Oxford 2010, p. 211; A.J. Kosto, Hostages in the Middle Ages, Oxford 2012, p. 101. 
of Psie Pole [Hundsfeld] near Wrocław, fabricated in the late twelfth/ early thirteenth century by the Polish chronicler Master Wincenty Kadłubek $^{7}$ ). The principal source for tracing the course of this expedition is the extensive narrative recorded in the contemporary chronicle of Poland written between 1113 and 1116 by Gallus Anonymous, and a shorter account penned sometime after 1110 by the Czech historian Cosmas. The overall effect of the war is also described in another contemporary account by Ekkehard, abbot of Aura (Franconia), author of the Universal Chronicle, the last two books of which deal with the reign of Henry V. ${ }^{8}$ Additional details, albeit unlikely ones, feature in later Polish histories: the aforementioned Wincenty Kadłubek's Chronicle of Greater Poland (the date of which is contested as either late thirteenth or mid-fourteenth century) and the fifteenth-century Annals of Jan Dtugosz. ${ }^{9}$ Brief references also appear in some German annals, though the only event of the war recorded by most of them is the death of Svatopluk, Duke of Bohemia.

The earliest scholarly Polish historiography (from the late eighteenth century) drew heavily on later chronicles, particularly that of Jan Długosz. With no new information at his disposal to add to that provided by Gallus, Długosz embellishes virtually every sentence he writes with his own speculative ideas. Initially, only one of his conjectures was rejected, namely that Svatopluk's killer had been sent

7 Magistri Vincenti dicta Kadtubek Chronica Polonorum, ed. M. Plezia, MPH s.n., vol. 11, Kraków 1994, lib. III, cap. 18. For an overview of opinions about this purported battle, see K. Kościelniak, 'Stan badań nad starciem pod Wrocławiem podczas wyprawy Henryka V na Polskę w 1109 roku' [Summary of research into the skirmish near Wrocław during Henry V's expedition to Poland in 1109], Studia z Dziejów Polskiej Historiografii Wojskowej, 9, 2005, pp. 57-68; K. Ziółkowski, 'Mityczne spotkanie dwóch armii w historiografii. Starcie na Psim Polu pod Wrocławiem w 1109 r.' [The mythical meeting of two armies in historiography. The skirmish at Psie Pole near Wrocław in 1109], in: Mity i legendy w polskiej historii wojskowości, eds. W. Caban and J. Smoliński, vol. 1, Kielce 2014, pp. 44-52.

8 Ekkehardi Uraugiensis Chronica, ed. G. Waitz, MGH SS, Bd. 6, Hannoverae 1844 , p. 243. For an overview of sources on this war, see R. Roepell, Dzieje Polski do XIV stulecia [A history of Poland up to the fourteenth century], Poznan 2005 (German edition 1840), pp. 362-363; G. Meyer von Knonau, Jahrbücher des Deutschen Reiches unter Heinrich IV und Heinrich V, Bd. 6, Leipzig 1907, pp. 98-100; K. Maleczyński, Wojna polsko-niemiecka 1109 r., Wrocław 1946, pp. 35-36; idem, Bolesław III Krzywousty..., pp. 100-101, n. 114. Two later (thirteenth-century) sources of minor value are highlighted by A.F. Grabski, Polska $w$ opiniach obcych X-XIII $w$. [Poland in foreign opinion, tenth to thirteenth centuries], Poznań 1964, p. 202, n. 96.

9 Jan Długosz, Annales seu cronicae incliti Regni Poloniae, lib. III-IV, Varsoviae 1970, p. 247. 
by Bolesław Krzywousty. ${ }^{10}$ It was considered that the Polish prince could not have been guilty of such 'shameful collusion' in this crime. ${ }^{11}$ Nevertheless, by the early nineteenth century some of Poland's more accomplished scholars had begun to raise questions, in particular about the mythical Battle of Psie Pole. As a result of their research, from the latter half of the nineteenth century ${ }^{12}$ till around 1938, the conflict that had taken place on the outskirts of Wrocław was regarded as one of Poland's national myths, and was omitted from scholarly descriptions of the war and from academic textbooks. However, it made a comeback as an alleged historical fact - though not as a critical, major battle but as a victorious skirmish fought by the Polish army against German forces-just before the outbreak of World War II, at a time when Polish-German relations were becoming increasingly strained. ${ }^{13}$ After 1945, in the understandably anti-German climate which prevailed in Poland following World War II, attempts were made to restore this fictional battle not only to the status of a genuine battle, but also to that of a decisive one. Given the post-World War II division of Europe into two hostile political blocs, it was deemed unnecessary to draw excessive attention to the role that Czechs had played as German allies in the 1109 battle against Poland. Thus, the claims of the battle's 'inventor', Wincenty Kadłubek, about the participation of Czech forces in the Battle of Psie Pole (he asserted that a phalanx of troops from Prague went into battle at the head of Henry V's army and fell during the first offensive) were overlooked. One of the major works on the subject of this war, published in 1961 and written by Benon Miśkiewicz, a military historian and communist activist pursuing a political career, made only one brief mention of Czech reinforcements having supported the efforts of Henry V's army. Everything else is omitted, including Svatopluk's tragic death during this expedition. Even the accompanying map showing army movements fails to show the direction taken by Czech troops. ${ }^{14}$

10 A. Naruszewicz, Historia narodu polskiego [A history of the Polish nation], vol. 2, 1780, cited after the Kraków edition, 1859, p. 159.

11 H. Schmidt, Rys dziejów narodu polskiego [An outline history of the Polish nation], vol. 1, Lwów 1855, p. 542.

12 In particular after the publication of B. Sikorski's study, 'O bitwie na Psiem Polu i o nazwisku' [On the Battle of Psie Pole and its name], Biblioteka Warszawska 3, 1873, pp. 36-50.

${ }_{13}$ K. Maleczyński, ‘Wyprawa Henryka V...,’ pp. 43-49.

14 B. Miśkiewicz, Studia nad obrona..., p. 271 (map). 
At present, the Battle of Psie Pole is once again firmly regarded as a myth in the historiography of Poland. It is only sporadically that attempts are made to champion its historical authenticity, suggesting that its extent was limited to a clash between the army of Bolesław Krzywousty and only part of Henry V's forces. But even those eager to resurrect the legend of this battle remain silent about the involvement in it of Czech auxiliaries..$^{15}$ Moreover, the assertions made by proponents of this legend are heavily criticized. ${ }^{16}$

Henry V launched his expedition against Poland (expeditio generalis) in Saxony after the Feast of Pentecost (13 June 1109). His troops massed in Erfurt, where it is documented that the king remained until 1 August of that year. ${ }^{17}$ The most complete description of the German army is provided by Cosmas, who mentions troops from Lorraine, Franconia, Bavaria, and Saxony. ${ }^{18}$ Initially in Polish historiography, the German forces available to Henry V were estimated at $10,000 .^{19}$ In later years, some scholars revised this figure to several thousand, though nonetheless emphasizing the considerable advantage that

15 K. Bobowski, 'Bitwa na Psim Polu - w 875-lecie (Refleksje dyskusyjne)' [The Battle at Psie Pole on its $875^{\text {th }}$ anniversary (Discursive reflections)], Chrześcijanin a Współczesność, 1, 1984, pp. 16-21; idem, 'Próba ponownej interpretacji zagadnienia wojny polsko-niemieckiej w 1109 roku' [An attempt to re-appraise the Polish-German war of 1109], in: Bolestaw III Krzywousty i jego czasy. Materiały z sesji naukowej zorganizowanej $w$ Głogowie $w$ 900. rocznice urodzin władcy Polski, Legnica 1985, pp. 65-74.

16 M. Cetwiński, Historia i polityka. Teoria i praktyka mediewistyki na przyktadzie badań dziejów Ślaska [History and politics. The theory and practice of medieval studies based on the example of research into the history of Silesia], Kraków 2008, pp. 164-165; J. Maroń, O osobliwościach polskiej historii wojskowości [The idiosyncrasies of Polish military history], Wrocław 2013, pp. 139-140.

17 Monumentorum Boicorum, Bd. 29, Munich 1831, no. 437, pp. 222-223.

18 Cosmas, lib. III, cap. 27.

19 See the discussion in K. Maleczyński, 'Wyprawa Henryka V...,' p. 44, idem, Wojna polsko-niemiecka..., p. 11; idem, Bolesław III Krzywousty..., p. 110, n. 155; K. Myśliński, review of K. Maleczyński, Wojna polsko-niemiecka..., RH, 16, 1947, p. 258; W. Korta, 'Jak doszło do Psiego Pola, w 850 rocznicę wojny polsko-niemieckiej z 1109 roku' [The events that led to the Battle of Psie Pole, on the 850th anniversary of the Polish-German war of 1109], Rocznik Wroctawski, 2, 1958, pp. 104-105; A. Kucner, 'O przebiegu wojny polsko-niemieckiej w roku 1109,' in: Nadodrzańskie szkice historyczne, Zielona Góra 1960, p. 57; A.F. Grabski, Polska sztuka wojenna..., p. 185; A.F. Grabski, A. Nadolski, 'Wojskowość polska w okresie wczesnofeudalnym (do roku 1138)' [The Polish military of the early feudal period (up to 1138)], in: Zarys dziejów wojskowości polskiej do roku 1864, vol. I, Warszawa 1965, p. 28; G. Labuda, 'Bolesław Krzywousty i jego czasy (1085-1102-1138). Jakim był?, jak go widzimy?, jak go oceniamy?' [The life and times of Bolesławs Wrymouth (1085 - $1102-1138)$ What was he like? How do we perceive him? How do we judge him?], in: Bolestaw III Krzywousty. W 900 rocznicę urodzin, ed.W. Kowalewski, Płock 1988, p. 48. 
the German army held over Poland's forces, both in terms of numbers and equipment, ${ }^{20}$ while other researchers maintained that the German troops had numbered $10,000 .^{21}$

It was not until recently that the number of Czech troops led by Svatopluk was given separate consideration and estimated at 2,000. ${ }^{22}$ No indication was given of how this figure had been calculated, but it was most likely based on the information that Svatopluk's personal enemy, Wiprecht von Groitzsch of Meissen, brother-in-law of the exiled Bořivoj, had provided Henry with 2,000 knights and retainers. ${ }^{23}$ However, in both cases (Svatopluk and Wiprecht), these estimates appear to be exaggerated. ${ }^{24}$ Czech forces supplied as part of feudal obligations to German rulers during the eleventh and twelfth centuries usually amounted to no more than 300 armed men. ${ }^{25}$ Given Svatopluk's ambition-driven involvement in the 1109 expedition against Poland, he may well have taken a greater number of troops with him, though probably not twice as many as usual. The accounts provided by Cosmas and Gallus appear to suggest that the Czech army consisted predominantly of cavalry, both authors indicating that Czech troops had participated in the looting of Silesia rather than in the siege of Głogów.

Poland's fighting force was estimated at 3,000-4,000. This modest number of Polish troops was the result of Bolesław Krzywousty's Pomeranian campaign and the great battle his army had fought on 10 August at the Pomeranian stronghold of Nakło, where they had claimed victory but at the expense of heavy losses. Gallus points out

K. Maleczyński, ‘Wyprawa Henryka V...,' p. 44, idem, Wojna polsko-niemiecka..., p. 11, idem, Bolesław III Krzywousty..., p. 110, n. 155; W. Korta, 'Jak doszło...,' pp. 104-105; A. Kucner, 'O przebiegu wojny...,' p. 57.

20 A.F. Grabski, Polska sztuka wojenna..., p. 185; A.F. Grabski, A. Nadolski, 'Wojskowość polska...,' [The Polish military], p. 28; G. Labuda, 'Bolesław Krzywousty i jego czasy...,' [The life and times of Bolesław Wrymouth], p. 48.

21 J. Szymczak, 'Glogow...,' p. 211.

22 K. Olejnik, Głogów..., p. 86; J. Szymczak, ‘Glogow...,’ p. 211.

${ }_{23}$ Annales Pegavienses et Bosovienses, MGH SS, ed. G.H. Pertz, Bd. 16, Hannover 1859, pp. 250-251.

${ }^{24}$ Doubts about the number of Wiprecht's troops are raised by A.F. Grabski, Polska sztuka wojenna..., p. 183.

25 See J. Sobiesiak, Od Lechowego Pola (955) do Mediolanu (1158). W stużbie monarchów Rzeszy. Relacje czeskich źródet narracyjnych o wyprawach Przemyślidów [From Lechowe Pole (955) to Milan (1158). In the service of the monarchs of the Holy Roman Empire. Accounts of the Přemyslid expeditions in narrative Czech sources], Lublin 2011. 
that to counter the German invasion Bolesław had to quickly transfer his troops from Pomerania to Głogów on the Oder, and that many of his men were already wounded and exhausted by the Pomeranian campaign, while many others had died during it. Older historiography recorded that the Polish ranks had included the Czech exile Borivoj, claiming that he had fought against Henry $\mathrm{V}$ with a sizeable number of Czech followers, who had defected from Svatopluk's command. ${ }^{26}$

Virtually all of the literature published in Polish (and some in other languages) identifies the route chosen by the advancing German army as the same one they had taken when marching on Poland during the wars of 1005-1017, fought between the Polish prince Bolesław Chrobry (Bolesław the Brave) and the Holy Roman Emperor Henry II: hence, via Merseburg, Cottbus, and Gubin to Krosno Odrzańskie, from where, after crossing the Oder River, they were to attack Greater Poland, which was then the central region of the Polish state. The German forces were believed to have taken this route because of a mention made in the Kronika wielkopolska (Chronicle of Greater Poland), which records that in 1239 the then archbishop of Magdeburg, Wilbrandt, laid siege to the stronghold of Lubusz, located just north of Krosno Odrzańskie, claiming that during the reign of a Polish ruler named Bolesław, Lubusz had been captured by an emperor named Henry and gifted to the church of Magdeburg. ${ }^{27}$ The Kronika wielkopolska, unaware of Bolesław Chrobry's struggles with Henry II, connected these facts with the war of 1109 . Despite numerous doubts being raised about whether there was any merit in this account, it was nonetheless recognised as an episode in the war of 1109.

However, because Gallus Anonymous begins his account of the war with a description of events at Bytom Odrzański (by today's roads around $80 \mathrm{~km}$ south-east of Krosno Odrzańskie), clearly stating that this was where Henry V first witnessed the bravery of the Poles (there was a minor clash with the stronghold's defenders), scholars who still believed in the version of events recorded in the Kronika wielkopolska came to the conclusion that at some point while at Krosno,

26 This view is propounded by A. Naruszewicz, Historia..., p. 157 no small number of Czechs fought on the Polish side, having fled from Bohemia to escape the cruelty of Svatopluk.

27 Chronica Poloniae Maioris, cap. 67, p. 86. 
Henry V's army had decided on a change of plan. ${ }^{28}$ Instead of launching an assault on Greater Poland, they chose to proceed along the left bank of the Oder to Głogów, and thus to attack Silesia. The courage shown by the men of the Krosno stronghold, who also defended the local river crossing of the Oder, was proffered as an explanation for this revised strategy. However, this conjectured scenario is starkly at odds with the narrative of Gallus Anonymous, who notes every Polish success in great detail and with understandable hyperbole. He makes no mention of the purported actions of Krosno's defenders, who were supposed to have successfully held off the entire German army. Thus, a different explanation was sought for the change in Henry V's plans, attention finally focusing on the Czechs. At the very beginning of his account of the war, Gallus states that Czech troops were to have played an important role as guides because of their good knowledge of the roads and tracks that led through the dense Polish forests. ${ }^{29}$ And so it was suggested that the late arrival of Duke Svatopluk and his army may have been the reason for Henry V's having altered his plans. It is now widely claimed that without the Czechs as guides, Henry was fearful of negotiating the treacherous, muddy forests of Greater Poland and so changed route and set off for Głogów alone so that the two armies could join forces more quickly. ${ }^{30} \mathrm{It}$ is difficult, however, to take this speculation seriously. The Gubin-Krosno-Greater Poland trade route, which the army was supposed to have followed, was very well known to the Germans in particular, so there would have been no need to use Czech guides. And how could the Czechs have been expected to know the roads and tracks of Greater Poland better than the Germans, given that this region, located between the Oder and Obra rivers, lay so far away from Bohemia? ${ }^{31}$

The decidedly minority view that the Czech and German armies did indeed join forces at Krosno Odrzańskie does not stand up to scrutiny

28 The earliest Polish historiography knew nothing of this alleged change of plan; see Naruszewicz, II, p. 153.

29 Gall, lib. III, cap. 3.

30 This view is advocated principally by K. Maleczyński, 'Wyprawa Henryka V...,' p. 45; idem, Wojna polsko-niemiecka..., p. 15; more recently, see V. Vanicek, ‘Bohemi, infestissimi Polonorum inimici?” Literarni emoce a politycke reality od Galla Anonima po Jndricha z Isernie,' in: Klio via et invia. Opuscula Marco Cetwiski dedicata, ed. A. Odrzywolska-Kidawa, Warszawa 2010, p. 50.

31 Naruszewicz makes a now long-forgotten but apposite observation (Historia..., vol. 2, p. 151) that Svatopluk had offered to act as a guide through the forests that separated Bohemia from Poland (not Germany from Poland). 
any better. According to the proponent of this theory, it was the Czechs who were supposed to have informed the Germans of the formidable fortifications at Krosno Odrzańskie, which in turn prompted the change of route. However, this contradicts Gallus's claim that Henry V was greatly disappointed when, in the process of travelling from Krosno Odrzańskie to Głogów, he passed the stronghold of Bytom Odrzański and found it to be excellently situated, amid water and marshlands, and with sturdy, well-prepared defences. ${ }^{32}$ This implies that the Czechs were apparently well aware of conditions at Krosno Odrzańskie, which lay much further north of their lands, but had no idea about the strength of the much closer-lying Bytom Odrzański. ${ }^{33}$ This is entirely at odds with Gallus's opinion about the Czechs' knowledge of roads and tracks in Poland.

However, if we disregard the debatable interpretation of the late mention in the Kronika wielkopolska about Lubusz, which remained within the bounds of Poland up until the 1220 s, a very different picture of the overall situation begins to emerge. It seems altogether strange that despite many scholars being sceptical about the late account featured in this chronicle (and its assertion about someone having laid claim to something on the strength of a centuries-old gift of property), it had such a great impact on charting the history of the war. All the more so given that Gallus makes no mention of Henry V's having intended to attack Greater Poland. He does, however, twice refer to the fact that the German king with his army at the ready in Silesia had threatened to attack Kraków. Thus, Gallus paints a consistent picture, as the Czechs would indeed have known the roads of southern Poland, Silesia, and the Kraków lands better than the Germans.

Consequently, all previous speculative scenarios should be rejected. First and foremost, there is no reason why the German army would have had to advance through Krosno Odrzańskie with the intention of crossing the Oder there (Gallus makes no mention of such events). Likewise, Svatopluk's Czech forces were not late in reaching their pre-arranged rendezvous point in Głogów. Henry V is far more likely

32 K. Olejnik, Głogów..., p. 91.

33 Ibidem, map on pp. 86-87; idem, 'Cedynia...,' map on p. 64, which shows the route taken by Czech forces in the campaign of 1109 (Prague-Kłodzko-LegnicaGłogów) to be different from that described in the text. If the author had revised his opinion and the idea that the German and Czech armies had joined forces at Krosno Odrzańskie, the Czechs would have had to cover the Głogów-Krosno stretch of their journey twice: there and immediately back again. 
to have proceeded from Erfurt to Leipzig, crossing the Lusatian Neisse at Zgorzelec (Görlitz), and the Bóbr River either at Żagań (Sagan) or Szprotawa (Spottau), which was the same route taken in 1157 by another German expedition against Poland launched by the emperor Frederick Barbarossa. ${ }^{34}$ It is worth underlining that when writing about the German army's march from Bytom Odrzański to Głogów, Gallus plainly stated that they made slow progress through the Polish forests. ${ }^{35}$ Thus, there is no indication of any haste; Henry was steadily making his way to Głogów to meet up, as arranged, with Svatopluk's Czech troops. Henry reached Głogów earlier than planned and launched his first attack even before Svatopluk had arrived. ${ }^{36}$ Luck was on Henry's side; hot, summer weather conditions prevailed throughout the course of the war. ${ }^{37}$ Despite Bolesław Krzywousty's orders to block all Oder crossings, German scouts managed to locate some unexpected shallows (caused by the river's low water level) just north of Głogów. At least part of Henry’s army crossed the river at this point, immediately routing an unsuspecting Polish auxiliary cavalry unit that had been sent to Głogów by the Polish king. The sight of the vanquished Poles prompted Głogów to enter into negotiations with Henry V. When news of this reached Bolesław he threatened

34 See, for example, J. Partsch, Schlesien. Eine Landeskunde für das deutsche Volk auf wissenschaftlicher Grundlage, Th. 1, Breslau 1896, p. 348; W. Semkowicz, Geograficzne podstawy Polski Chrobrego [The geography of Chrobry's Poland], KH, 39, 1925, pp. 263, 271-272; E. Kowalczyk, 'Wały Śląskie. Z zagadnień obrony stałej ziem polskich we wczesnym średniowieczu' [Silesian fortifications. Issues concerning the permanent defence of Polish territories in the early medieval period], in: Szprotawski epizod zjazdu gnieźnieńskiego w 1000 roku, ed. H. Szczegóła, Szprotawa 2000, pp. 59-60.

35 Gall, lib. III, cap. 3.

36 Cosmas claims that Czech troops became involved in the war in September 1109, and because we know that Henry's forces had already engaged in battle at Głogów on 25 August, it was assumed in historiography (Polish, Czech, and German) that the Czech chronicler had got his dates wrong. There is no need to dwell on this. Polish historiography includes occasional mentions of the Germans and Czechs having joined forces before 24 August, and of their having negotiated the unexpectedly discovered ford across the Oder together and then attacking Polish auxiliary troops at Głogów, which is inconsistent with the accounts given by both Gallus and Cosmas. See, among others, A. Nowakowski, Wojskowość w średniowiecznej Polsce [Warfare in medieval Poland], Malbork 2005, p. 170. On 24 August 1109 the Czechs, 'long awaited' by Henry V, arrived at Głogów.

37 B. Śliwiński, 'O pogodzie w Polsce w sierpniu i wrześniu 1109 roku' [The weather in Poland in August and September of 1109], in: Księga pamiatkowa poświęcona Mariuszowi Mierzwinskiemu (in press), where attention is drawn to Gallus's mentioning that during the period from 14-15 to 21 September the Germans and Czechs were pestered by biting flies (which would have been inactive in cold, adverse weather). 
to crucify its residents (men, women, and children) if they decided to surrender the stronghold.

The Czech forces, which are believed to have marched from Prague via Kłodzko and Legnica to Głogów, ${ }^{38}$ arrived in Głogów after these negotiations had broken down and took part in the first assault on the stronghold's defences. The fruitless siege of Głogów lasted from 25 August to around 14-15 September. Gallus reports that the bodies of the more notable German dead were taken back to their homeland. Centuries later Jan Długosz embellished this episode by adding his own supposition that the fallen Czechs were buried near their camp at the foot of the Głogów stronghold. ${ }^{39}$ This assertion was subsequently reiterated by some Polish scholars. ${ }^{40}$ However, neither Gallus nor Cosmas make any mention of the Czechs' having suffered losses during the siege of Głogów, which is consistent with the theory that the Czech cavalry looted the surrounding area, playing little if any role in the siege.

The two chronicles provide divergent accounts of this siege. Gallus relates that, having witnessed the futile attempts to capture Głogów, Henry V consulted his advisors and decided to abandon the siege and 'move camp' towards Wrocław (Breslau). ${ }^{41}$ Gallus's version of events clearly implies that all troops left Głogów. In contrast, Cosmas recounts that Henry first ordered the siege of Głogów then sacked the lands on either side of the Oder from Głogów up to the stronghold of Recen, after which he returned to camp with a wealth of spoils and ordered that Svatopluk and his troops be sent away from the expedition the very next day. He ends his account with a description of Svatopluk's murder on the night of 21 September, when returning from a meeting with Henry V, after having gained permission to go back to his homeland. ${ }^{42}$ Cosmas's narrative suggests that both the camp to which Henry returned from his expedition

38 A.F. Grabski, Polska sztuka wojenna..., p. 188; K. Olejnik, Gtogów..., map on pp. 86-87; idem, 'Cedynia...,' map on p. 64.

39 J. Długosz, Annales..., p. 247.

40 A. Naruszewicz, Historia..., p. 157; J.S. Bandtkie, Dzieje narodu polskiego [The history of the Polish nation], vol. 1, Wrocław 1835, p. 215; J. Lelewel, 'Historia Polska do końca panowania Stefana Batorego' [The history of Poland up to the end of Stefan Batory's reign], in: idem, Polska dzieje i rzeczy jej, vol. 13, Poznań 1863, p. 72 (a posthumous edition of the 1810 publication); J. Bartoszewicz, 'Historia pierwotna Polski' [The early history of Poland], vol. 3, in: idem, Dzieła, Kraków 1879, p. 183.

41 Gall, lib. III, cap. 10.

42 Cosmas, lib. III, cap. 27, p. 195. 
to the Recen stronghold and the one where Svatopluk met his death were located in Głogów. Finally, the later Kronika wielkopolska notes that in response to the attacks of Bolesław Krzywousty's forces on Henry's camp in Głogów, Svatopluk advised that part of the army be sent to try and take Wrocław. The chronicle records that this task force was routed by Bolesław's army. Following this victory, the Polish prince was supposed to have reappeared at Henry's camp and instigated the Battle of Psie Pole, which ended in defeat for the Germans and the Czechs, the latter having fought in the vanguard.

The earliest Polish history books acknowledged the account recorded in the Kronika wielkopolska (repeated by Jan Długosz) as the best. Scholars of the day added their own observations, asserting that because Svatopluk had been behind the idea to march on Wrocław, it was he who had led the Czech troops to that city and, having been defeated, returned to Henry's camp in Głogów. However, it was believed that Svatopluk had been murdered at this camp (by an assassin sent by Wiprecht von Groitzsch), which was supposed to have prompted the Czechs to return to their homeland, leaving Henry to continue the war without them and suffer the alleged defeat at Psie Pole. ${ }^{43}$

In the mid-nineteenth century there was a shift in opinion. ${ }^{44}$ Attention was drawn to the fact that Psie Pole lies near Wrocław (today it is a district of that city) and not Głogów. It was, therefore, concluded that the earlier interpretation had been erroneous, and that the story

43 A. Naruszewicz, Historia..., p. 158 (Wiprecht is accused of the murder, which is wrongly dated to 11 October; there are also contradictory conjectures, firstly claiming that the Czechs departed, and then-in keeping with Polish chroniclers from Master Wincenty onwards-stating that they had taken part in the Battle of Psie Pole); J.S. Bandtkie, Dzieje..., pp. 215-216 (Wiprecht is accused of the murder, but there is no mention of the Czechs' involvement in the alleged Battle of Psie Pole); J. Bartoszewicz, 'Historia pierwotna...,' p. 184; W. Bogusławski, Dzieje Stowiańszczyzny pótnocno-zachodniej do połowy XIII wieku [The history of the north-western Slavs up to the mid-13th century], vol. 3, Poznań 1892, p. 497. J. Szujski, Dzieje Polski podtug najnowszych badań [The history of Poland according to recent research], vol. 1, Lwów 1862, p. 95; see also F. Minsberg, Geschichte der Stadt und Festung Gross-Glogau, Bd. 1, Glogau 1853, p. 26. There was, however, no shortage of Polish scholars who faithfully adhered to Gallus's version of events. See J. Faleński, Historia Polski krótko zebrana dzieje narodowe od powstania aż do podziału i upadku państwa tego obejmujaca [A brief history of Poland from the formation to the division and collapse of this state], Wrocław 1818, p. 52.

${ }_{44}$ The first outline of this new outlook was provided by J. Lelewel, Dzieje..., p. 74, who omitted any description of the alleged Battle of Psie Pole from his work, though he did maintain the view that the Czech forces had left (after Svatopluk's murder) while the campaign was ongoing. 
recorded in the Kronika wielkopolska was entirely unreliable. Thus, at one fell swoop, both the version of events recounted in the Kronika wielkopolska was dismissed and the veracity of Master Wincenty's account of the purported Battle of Psie Pole was questioned. ${ }^{45}$ This left only the narratives of Gallus and Cosmas. Because of the level of detail recorded by Gallus, it was now his version which was regarded as the best ${ }^{46}$. Hence, it was thought that after about three weeks Henry $\mathrm{V}$ abandoned the siege of Głogów and together with his entire army, including Svatopluk's Czech troops, moved on to Wrocław.

The problem of how the accounts written by Gallus and Cosmas relate to one another re-emerged in the late 1930s. Cosmas's version was championed at that time by Karol Maleczyński. ${ }^{47}$ Based on this narrative, he argued that Henry V, while camped at Głogów, had carried out a series of local raids, reaching as far as the stronghold of Recen. This theory resulted in attempts being made to identify this stronghold with Ryczeń, located $30 \mathrm{~km}$ east of Głogów, on the River Barycza. ${ }^{48}$ However, Cosmas himself had already mentioned the Recen stronghold twice in his chronicle. The first time is when writing about the reign of Břetislav I, duke of Bohemia, pointing out that the duke had frequently attacked Poland from 1093 onwards, resulting in the lands

$45 \quad$ H. Schmidt, Rys dziejów..., p. 541; J. Moraczewski, Dzieje Rzeczypospolitej Polskiej [The history of the Republic of Poland], vol. 1, Poznań 1862, p. 82; B. Kalicki, Opowiadania $z$ dziejów Polski [Stories from the history of Poland], vol. 1, Lwów 1871, p. 104; B. Sikorski, 'O bitwie na Psiem Polu...' pp. 36-50.

${ }_{46}$ Advocates of Gallus's version included C. Grünhagen, Geschichte Schlesiens, Bd. 1, Gotha 1884, p. 12; C.R. Needon, Beiträge zur Geschichte Heinrichs V. Die Anfänge seiner Regierung 1105-1110, Leipzig 1885, p. 61; B. Dudik, Mährens Allgemeine Geschichte, Bd. 2, Brünn 1863, p. 553 and V. Novotny, České dějiny..., p. 464, n. 2; A. Lewicki, Dzieje narodu polskiego w zarysie [An outline history of Poland], Warszawa 1899, pp. 54-55; M. Gumplowicz, 'Zbigniew Grossherzog von Polen (1102-1107),' in: Zur Geschichte Polens im Mittelalter, Innsbruck 1898, p. 78; F. Koneczny, Dzieje Polski za Piastów [The history of Poland under the Piast dynasty], Kraków 1902, pp. 146-147; G. Artler, 'Die Zusammensetzung deutscher Streitkräfte in den Kämpfen mit den Slaven von Heinrich I bis auf Friedrich I,' Zeitschrift für thüringische Geschichte und Altertumskunde, 21, 1913, H. 2, p. 312.

47 K. Maleczyński, 'Wyprawa Henryka V...,' the author expanded on this subject in later works. See idem, Wojna polsko-niemiecka..., p. 26; idem, 'Ślask terenem wojen...,' p. 214; W. Korta, 'Z dziejów obrony Śląska...,' p. 98; see K. Olejnik, 'Cedynia...,' pp. $65-67$.

48 A.F. Grabski, Polska sztuka wojenna..., p. 191; A. Nadolski, 'Uwagi o metodzie badań nad wczesnośredniowieczna wojskowością polską (na marginesie pracy A.F. Grabskiego)' [Notes on research methods into early medieval Polish warfare (comments on the work of A.F. Grabski)], KHKM, 8, 1960, pp. 356-357; K. Olejnik, 'Cedynia...,' p. 67; idem, Głogów..., p. 103. 
between Recen and Głogów being so badly ravaged that only the stronghold in Niemcza survived. ${ }^{49}$ In this instance, there is no doubt that the Recen referred to was Ryczyn, which stands on the right bank of the Oder, where there was a crossing of this river, between Olawa (Ohlau) and Brzeg (Brieg), some 120-130 km south-east of Głogów and around $38 \mathrm{~km}$ from Wrocław. ${ }^{50}$ On the second occasion, Cosmas mentions the Recen stronghold as the site where the Czech dukes Bořivoj and Svatopluk had made camp in 1103 while coming to the aid of Zbigniew. ${ }^{51}$ This simply has to be the same stronghold as before. The fact that Cosmas mentions a stronghold of the same name three times (the third reference being the one concerning events in 1109) firmly rules out the possibility that he is referring to different sites. ${ }^{52}$ Accordingly, it was also wrong to imagine that the mention relating to 1109 was a reference to Ryczeń on the Barycza. ${ }^{53}$ This issue was finally resolved when archaeologists excavated this site in 1962, determining that the stronghold dated at earliest from the mid-thirteenth century ${ }^{54}$ Having ruled out that the Recen stronghold might have been Ryczeń, which lay nearer Głogów, some scholars who still favoured Cosmas's version of events, reverted to the idea that Henry V had carried out long-distance raids from his camp in Głogów all the way to Ryczyn. ${ }^{55}$

However, the idea that Henry would have undertaken such long-range sorties, which would have additionally entailed the division of his German-Czech forces, seems highly improbable. It is all the more

49 Cosmas, lib. III, cap. 1, p. 161.

50 J. Kramarek, Wczesnośredniowieczne grodziska ryczyńskie na Ślasku [The early medieval Ryczyn strongholds in Silesia], Wrocław-Warszawa-Kraków 1969, pp. 20-21, 31-33, 132-133.

51 Cosmas, lib. III, cap. 1, p. 179.

52 As claimed by M. Cetwiński, ‘Głogów w kronikach polskich’ [Głogów in Polish chronicles], in: Glogovia Maior. Wielki Głogów między blaskiem dziejów a cieniem ruin, eds. B. Czechowicz and M. Konopacka, Głogów-Zielona Góra 2010, p. 24.

${ }^{53}$ As claimed by B. Miśkiewicz, Studia nad obrona..., p. 277, n. 204; see also S. Rosik, Bolesław Krzywousty, Wrocław 2013, pp. 117-118.

${ }_{54}$ J. Kramarek, 'Wyniki badań w Ryczeniu, pow. Góra Śląska i zagadnienia lokalizacji grodu Recen w wojnie 1109 roku' [Excavation results from Ryczeń, Góra Ślaska District, and questions surrounding the location of the Recen stronghold in the war of 1109], Silesia Antiqua, 6, 1964, pp. 142-157.

55 The launch of an attack on Ryczyn all the way from Głogów had already been mentioned in older German historiography. See, for example, D.E. Wagner, Geschichte von Polen, Leipzig 1775, p. 123. More recently, S. Rosik, 'Bolesław Krzywousty,' in: S. Rosik, P. Wiszewski, Poczet polskich królów i ksiażat, Wrocław 2006, p. 182; S. Rosik, Bolestaw Krzywousty..., pp. 117-118. 
unlikely given Gallus's chronicle, which gives a step-by-step account of Henry's actions and clearly states that he departed from Głogów and that before reaching Wrocław he spent some time "wandering" along the Oder. ${ }^{56}$ It is this incident that we should associate with Henry's excursion to Ryczyn. It is worth reiterating how far away Ryczyn was: around 120-130 km from Głogów, and around $38 \mathrm{~km}$ from Wrocław. Hence, there is a third possibility. Namely, to give precedence to Gallus's account and to acknowledge that Cosmas, in his brief description of events, amalgamates the actions of the German and Czech forces in 1109, and that the camp which he mentions when describing the murder of Svatopluk was not located in Głogów. In contrast to Gallus, Cosmas devotes much less attention to the war of 1109 . Essentially, he is only interested in events relating to the death of Svatopluk, leader of the Czech forces, and on its repercussions for the Czech state. This goes some way to explaining the eagerness evident in his narrative to get to the description of Svatopluk's death as quickly as possible. The camp to which Henry V returned from Ryczyn (the stronghold located between Brzeg and Oława), and the one where Svatopluk was murdered, was thus, without doubt, the same one that Gallus reports the German king had set up after withdrawing from Głogów and setting off for Wrocław. The picture which emerges from Gallus's account is that after consulting with his commanders, Henry decided to abandon the siege of Głogów and head towards Wrocław with his entire army-including the Czech contingent. ${ }^{57}$ Gallus goes on to note (with considerable hyperbole) that on the way to Wrocław, partisan attacks by Bolesław Krzywousty's troops tormented the enemy army so badly that they dared not separate from the main force in search of food and spoils, and that even the Czechs, who were "born looters," had to eat their own supplies or fast. ${ }^{58}$ It can be inferred from this that the forces of Henry V and Svatopluk were not yet starving, and that the Czechs still had their own supplies of what was probably good-quality food, given that the alternative was to fast,

$56 \quad$ Gall. lib. III, cap. 15.

${ }_{57}$ As claimed, among others, by T. Nowak, J. Wimmer, Dzieje oręża polskiego do roku 1793 [The history of Poland's armed forces up to 1793], Warszawa 1968, p. 43; T. Nowak, J. Wimmer, Historia oręża polskiego 963-1795 [The history of Poland's armed forces, 9631795], Warszawa 1981, p. 79; W. Korta, Historia Ślaska do 1763 roku [The history of Silesia up to 1763], Warszawa 2003, p. 71; A. Nowakowski, Wojskowość..., p. 171; M. Barański, Dynastia Piastów w Polsce [The Piast dynasty in Poland], Warszawa 2005, p. 206.

58 Gall, lib. III, cap. 10. 
hence to eat modestly, which is some way from starving. Nonetheless, voices in Polish historiography also included one that radically altered the words of Gallus to state that the Czechs preferred to not eat or drink to avoid being massacred. . $^{9}$

Gallus is very vague about the events that took place in Wrocław, asserting only that Henry $\mathrm{V}$ gained nothing at this stronghold but corpses in place of living beings. As mentioned earlier, another Polish chronicler, Master Wincenty, turns this statement into the great Battle of Psie Pole, which then found its way into Polish historiography. It is worth adding that German historiography imagined that this site (if any) may have been where the German-Czech forces set up their next camp. Sick and wounded German warriors died at this camp, and because the Poles supposedly referred to Germans as "dogs," the site came to be known as Dog's Field (Psie Pole). ${ }^{60}$ Notwithstanding the above, the new camp set up by Henry and his army must have been located near Wrocław, and it was there that the king returned after his sortie to Ryczyn.

The camp near Wrocław was also where the unexpected murder of Svatopluk must have taken place. Cosmas's condensed account might suggest that this happened at the camp in Głogów; however, Gallus tells us about Svatopluk's death after recounting not only

$59 \quad$ W. Bogusławski, Dzieje Stowiańszczyzny..., p. 496.

60 Of the vast body of literature see, for example, D.E. Wagner, Geschichte von Polen, Leipzig 1775, p. 124; K.A. Menzel, Geschichte Schlesiens von dem ältesten Zeiten bis 1526 begreift, Breslau 1808, p. 16; M. Morgenbesser, Geschichte Schlesiens, Breslau 1833, p. 14; L. Giesebrecht, Wendische Geschichten aus den Jahren 780 bis 1182 , Bd. 2, Berlin 1843, p. 176, n. 3; R. Roepell, Dzieje Polski..., p. 136; R. Brükner, J. Stein, Geschichte der Stadt Bresalu von ihrer Gründung bis auf die neueste Zeit, Bd. 1, Breslau 1851, p. 7; F. Minsberg, Geschichte der Stadt und Festung Gross-Glogau, Bd. 1, Glogau 1853, p. 26; G. Stenzel, Geschichte Schlesiens, Bd. 1, Breslau 1863, p. 13; A. Pfaff, Deutsche Geschichte von den ältesten Zeiten bis zur Zeit dreissigjähringen Krieges, Bd. 2, Braunschewig 1864, pp. 238-239; C. Grünhagen, Geschichte Schlesiens..., p. 13; G. Arltler, 'Die Zusammensetzung deutscher Streitkräfte in den Kämpfen mit den Slaven von Heinrich I bis auf Friedrich I,' Zeitschrift für thüringische Geschichte und Altertumskunde, 21, 1913, H. 2, p. 312 (no mention at all is made of events in Wrocław, and Henry V is said to have retreated from Ryczyn); H. Loesch, 'Zum Chronicon Polono-Silesiacum,' Zeitschrift des Vereins für Geschcichte Schlesien, 65, 1931, p. 232; H. Aubin, J.J Menzel, W. Irgang, Geschichte Schelsiens von der Urzeit bis zum Jahre 1526, Bd. 1, Sigmaringen 1983, p. 83; E. Boshof, Das Salierreich und der europäische Osten, in Auslandsbeziehungen unter den salischen Kaisern, ed. F. Staab, Speyer 1994, p. 190, n. 122; idem, Europa im 12. Jahrhundert. Auf dem Weg in die Moderne, Stuttgart 2007, p. 21. Polish historiography also includes proponents of this view, see J. Lelewel, Dzieje..., p. 74; J. Moraczewski, Dzieje..., p. 82; J. Staszewski, Przeszłość wojenna Ślaska [Silesia's wartime past], Katowice 1938, p. 11. 
the events at Głogów, but also after mentioning that the GermanCzech forces had advanced towards Wrocław. Again, it is his timeline that should be given precedence. After all, why would Gallus, who gives such a detailed description of the war's progression, conceal the fact that Svatopluk had been murdered at Głogów if that was indeed where this event had taken place? A murder at the Czech camp would have added an even greater flourish to Gallus's extensive description of the defence of Głogów. Because he knew the actual course that events had taken, this did not even enter the chronicler's mind. Not all historians who have written about these events have clearly stated where Svatopluk met his unexpected death. ${ }^{61}$ The opinions of others on this matter can only be deduced from their writing. ${ }^{62}$ It should, however, be obvious that Svatopluk's assassination did not take place at the camp in Głogów, but in Wrocław.

It should also be stressed that Svatopluk's death occurred immediately after Henry $\mathrm{V}$ had declared the campaign to be over. On 21 September 1109 he informed Svatopluk that the Czech army would be dismissed from the expedition the next morning, and both men spent the whole day discussing matters of interest to them at Henry's court. ${ }^{63}$ A Czech knight assassinated Svatopluk as he made his way back at twilight (riding a mule according to Gallus). The assassin

61 For example, at Wrocław, H. Schmidt, Rys dziejów..., p. 542; A. Lewicki, Dzieje narodu polskiego..., p. 55 (see also, for example, V. Novotny, České dějiny, vol. I/2, Praha 1911, p. 464); at the camp between Wrocław and Ryczyn, C.W. Böttiger, Geschichte des Kurstaates und Königreiches Sachsen, Hamburg 1830, p. 98; B. Dudik, Mährens Allgemeine Geschichte..., p. 555; at the camp near Psie Pole, A. Małecki, 'Rewizja dziejów polskich w pierwszych dwóch wiekach politycznego istnienia' [A revision of Poland's history during the first two centuries of its political existence], in: idem, $Z$ przeszłości dziejowej pomniejsze pisma, vol. 1, Kraków 1897, p. 177; at the camp in Głogów, T. Flathe, 'Wiprecht von Groitzsch,' Archiv für die Sächsische Geschichte, 3, 1865, p. 109; O. Posse, Die Markgrafen von Meissen und das Haus Wettin bis zu Konrad dem Grosse, Leipzig 1881, p. 259; W. Grabieński, Dzieje narodu polskiego [History of the Polish nation], vol. 1, Kraków 1897, p. 28; W. Smoleński, Dzieje narodu polskiego [History of the Polish nation], Warszawa-Lublin-Łódź 1919 (5th edition), p. 24; M.R. Pauk, Działalność fundacyjna możnowtadztwa czeskiego i jej uwarunkowania spoteczne (X-XIII wiek) [The foundation activity of Czech nobles and its social context (tenth-thirteenth centuries], Kraków-Warszawa 2000, p. 14; M. Wihoda, Pruni česká království, Praha 2015, p. 74.

62 For example, at Wrocław, J. Lelewel, 'Historia Polska...,' pp. 72-73, K. Maleczyński, Wojna polsko-niemiecka..., p. 29; A.F. Grabski, Polska sztuka wojenna..., p. 192; at the camp in Głogów, A. Naruszewicz, Historia..., p. 162; Bartoszewicz, 'Historia pierwotna...,' p. 185; at the camp in Ryczyn, J. Kramarek, Wczesnośredniowieczne grodziska ryczyńskie..., p. 143.

63 Kosmas, lib. III, cap. 27. 
lay in wait under a spreading beech tree at the roadside, and when Svatopluk and his sizeable retinue approached, he mixed himself among them, threw a spear between the duke's shoulder blades (Gallus tells us the duke was pierced through with a javelin) and so took his life. The events which followed, starting from the morning of 22 September, when Henry V arrived in person at the Czech camp, have been discussed in multiple publications and there is no need to address this issue here. The very fact that Henry had granted permission for the Czech contingent to leave the expedition, which happened just before Svatopluk was murdered, demonstrates that a decision had already been made to bring the whole campaign to an end. ${ }^{64}$ The idea that it was Svatopluk's death that was the reason for dismissing the Czech troops from the expedition must be repudiated. ${ }^{65}$

For a long time, it was maintained that Henry V had retreated from Poland having achieved nothing and that the war had spontaneously fizzled out. Currently, Polish historians have no doubts that the war ended in peace negotiations. Debate is ongoing about the conditions which Bolesław Krzywousty was forced to accept, although he must have had to comply with Henry V's principal demands, namely to pay an annual tribute. ${ }^{66}$ Given that the German king had made at least (according to Gallus) three proposals that Bolesław Krzywousty sign a truce, we can conclude that Poland agreed to enter into peace negotiations at the point when the German and Czech forces were laying waste to Silesia from their camp in Wrocław all the way up to Ryczyn.

64 See, among others, G.A. Stenzel, Geschichte Deutschlands unter der Fränkischen Kaisern, Bd. 2, Lepizig 1828, p. 314; C.R. Needon, Beiträge..., p. 66, n. 19; G. Artler, ,Die Zusammensetzung...,' p. 312.

65 J. Lelewel, 'Historia Polska...,' p. 73; R. Roepell, Dzieje Polski..., p. 136; B. Dudik, Mährens Allgemeine Geschichte..., p. 554; J. Bartoszewicz, 'Historia pierwotna...,' p. 186; V. Novotny, České dĕjiny..., p. 465; W. Bogusławski, Dzieje Stowiańszczyzny..., p. 498; H. Schmidt, Rys dziejów..., p. 543; A. Małecki, 'Rewizja dziejów polskich...,' p. 116; K. Bobowski, 'Bitwa na Psim Polu...,' p. 19; M. Barański, Dynastia Piastów..., p. 206.

66 G. Labuda, O stosunkach prawnopublicznych między Polska a Niemcami w połowie XII wieku [Public-private relations between Poland and Germany in the mid12th century], CPH, 25, 1973, pp. 2558 (although the subject itself is not addressed and it is claimed that the war of 1109 ended in defeat for Henry V, an outline of the background is given); idem, 'Polsko-niemieckie problemy graniczne we wczesnym średniowieczu. (Przyczynek do dyskusji nad zaleceniami do podręczników szkolnych)' [Polish-German border problems in the early Middle Ages. (A contribution to discussion on recommendations for school textbooks)], in: Ślask i Pomorze w historii stosunków polsko-niemieckich w średniowieczu, XII Konferencja Wspólnej Komisji Podręcznikowej PRL-RFN Historyków 5-10 VI 1979 r., Olsztyn, Poznań 1987, p. 39; idem, 'Bolesław Krzywousty i jego czasy...,' p. 48. 
Bolesław Krzywousty's weak army was powerless to prevent this, and the threat of the enemy's marching on Kraków was probably also imminent, as Henry V (according to Gallus) had clearly announced. Thus, Henry's return from Ryczyn, as described by Cosmas, and his decision to send home the Czech troops took place at the point when the first peace talks had already begun and the war was deemed to be over. 